\title{
Celebrating Differences through Dialogue in Indonesia
}

\section{Syafaatun Almirzanah}

To cite this article: Syafaatun Almirzanah (2014) Celebrating Differences through Dialogue in Indonesia, Religious Education, 109:3, 234-245, DOI: 10.1080/00344087.2014.911617

To link to this article: http://dx.doi.org/10.1080/00344087.2014.911617

Tolink to this article: htp://dx.doi.org/10.1080/00344087.2014.911617

Published online: 28 May 2014.

Submit your article to this journal $₫$

L Article views: 129

Q View related articles $\square$



View Crossmark data $\longleftarrow$

Crossmank

Citing articles: 1 View citing articles ¿ 


\title{
CELEBRATING DIFFERENCES THROUGH DIALOGUE IN INDONESIA
}

\author{
Syafaatun Almirzanah \\ State Islamic University Sunan Kalijaga Jalan Marsda Adisucipto, \\ Yogyakarta, Indonesia
}

Plurality is a fact of our contemporary world, both on a global scale and often on the level of specific societies. Throughout most of recorded history, humanity has experienced a rich plurality of religions. This is due to the manifoldness of the divine revelation and of its human pursuit in different cultures. "Religions are many and varied and they reflect the desire of men and women throughout the ages to enter into relationship with the Absolute Being" (Pope John Paul II 1986, 2).

Plurality is also the very texture of Indonesia. In terms of religion in Indonesia, many researchers maintain that there is a demographic paradox: despite the huge Muslim majority population, Indonesia is constitutionally not an Islamic state. On the other hand, it is not a secular state either. Constitutionally it is a unitary state that embodies and simplifies a philosophy called Pancasila ("Five Principles"). These principles are: (1) belief in the one Supreme God; (2) a just and civilized humanity; (3) the unity of Indonesia; (4) democracy led by the wisdom of unanimity arising from deliberations among representatives of the people; and (5) social justice for the whole people of Indonesia.

Despite its religious diversity, Indonesia has until recently been generally known as a country where a number of great world religions meet and develop in peaceful co-existence. Indeed, most Indonesians are Muslims, and the rest are Christian (Catholic and Protestant), Hindus, Buddhist, Confucians, and even a very small Jewish community. The reality of religious pluralism is not just a matter of the historical past, but also a reality of the living present, reflected in curiosity about other religions, studying them at various levels and reading each other's scripture. As we do so, we are often inspired by each other's insights and practices. Sometimes we find in that our various traditions share some of the same fundamental values that each of us cherish in our own religions, albeit expressed in different ways. One might say that, to be religious today in Indonesia is to be inter-religious. Avoiding pluralism is avoiding the reality of different point of views and beliefs 
in society. From the beginning, people in Indonesia grappled with what social theorists today sometimes regard as a uniquely modern problem-cultural pluralism.

\section{PERSONAL EXPERIENCES}

Experiencing plurality is not something new in my life. My experience of plurality and dialogue was begun in my childhood and family. I came from a Muslim family. Although my father and mother came from different Islamic religious orientation, they never ask any of their children to follow one of them.

When I was twelve years old, they sent me to a pesantren (Islamic boarding school). This is a modern pesantren and does not belong to a certain Muslim group (as the leader said) but to Muslims in general. In this pesantren I studied all the groups in Muslim society and the leader never asked (much less forced) anyone to follow one of them. I also studied comparative religion (called muqaranah al-adyan course) in the pesantren. In fact we (santri) have had an opportunity to engage in dialogue with our brothers from the Roman Catholic Seminary Mertoyudan, one-hour drive from the pesantren. A seminarian used to live in my Islamic Boarding School for a certain time (one or two months).

I was in the pesantren for six years and after I graduated I registered for the State Islamic University, Faculty of Theology, Department of Comparative Religion. In this Islamic university I studied almost all the religions in the world. The method used here was not theological approach but phenomenological approach. We tried to do justice, letting every religion to talk about itself.

My interest in the study of Christianity, in fact, began when I had a course on the Development of Modern Christian Theology by Prof. A. Karel Steenbrink from Holland (Utrecht University). During this time also I realized that beginning interreligious dialogue from a doctrinal perspective, focusing almost exclusively on doctrinal differences, is inherently conflictual. This is why, when one of my colleagues asked the professor about the doctrine of the Trinity, he preferred not to discuss it. I remember being sympathetic to Prof. Steenbrink's desire not to allow conflictual doctrinal concerns dominate and shape efforts at interreligious understanding and comparative study. At the same time, however, I found myself eager to hear what he had to say about his Trinitarian beliefs. As a Muslim intellectual, I had my 
own presuppositions about Trinitarian theology, but I was also fully aware that those presuppositions developed in a kind of theological isolation. In other words, they were not the result of a genuinely dialogic engagement with Christian theology. This kind of experience encouraged me to explore how Christianity itself understands the doctrine of the Trinity, and made me wonder whether the more authentic Muslim understanding of this doctrine must be a dialogical one. In other words, I began to believe that the development of any genuine Islamic theology of Christianity (or any of the other religions of the world) must entail a willingness to listen to and try to understand what Christians or other religions have to say about their own faith experiences.

The other subject that caught my attention and continues to do so is Christian liberation theology. The topic was a subject of heated debate, not only in a Latin-American Christian context, but also in Indonesia. In 1988, when an Indonesian scholar published a book on the same subject, the government banned it because it was perceived to be communist, and therefore illegal according to Indonesian law. This case led me to explore what Christian liberation theology actually is. I wrote my B.A. thesis on Christian theologies of liberation and analogous teachings in the Islamic tradition.

After graduating from college, I became a lecturer in both Islamic and Catholic universities. I taught comparative religion, mysticism, and interreligious dialogue in the Islamic University. In the Catholic University I taught Islam. One of the aspects of this teaching experience that was so energizing for me was that there was no area that was forbidden to discuss, and therefore no obstructionist sense of "mystery" in the dialogue.

Besides teaching history of religions and interreligious dialogue, I also taught Islamic mysticism (Sufism), and my M.A. thesis project was on this topic. In this project I was first introduced to the figure of Meister Eckhart, as it was my task also to introduce comparative approaches to mysticism as part of the overall curriculum. Also, certain people who have written on comparative mysticism have made reference to Meister Eckhart in their discussions of aspects of the mysticism of Abu Hamid al-Ghazali or of Ibn 'Arabi, although without further explanation. My curiosity was peaked and I became determined to investigate the writings of Eckhart, again in search of possible points of contact between Medieval Latin Christian mysticism and Islamic mysticism. It was from my studies of Eckhart and Buddhist thought, as well, that I began to think that perhaps comparative mysticism 
could provide a basis for dialogue that-precisely because of its phenomenological emphasis (i.e., an emphasis on understanding, not only through the linguistic forms of doctrine but also through the internal experience of the person).

My interest in comparative mysticism brought me to Holland to study Meister Eckhart. Thus, in 1998 I was a Scholar in Residence at Utrecht University, the Netherlands, to prepare for Ph.D. study on Christian and Islamic Mysticism (my program in Indonesia). This time was mostly spent gathering material and observing the spiritual life in Dominican monasteries. Following this observation was the experience of immersion by staying in Coptic Catholic Seminary in Ma'adi, Cairo, Egypt, which has enriched my spiritual experience.

In addition to my career as a lecturer, I also work for a nongovernmental organization (NGO) called Interfidei (Institute for Interfaith Dialogue in Indonesia). An interreligious staff supports this institution. Crossing the boundaries as a vocation is not without risk. When certain people in my university discovered this involvement with Interfide $i$ as well as befriending non-Muslim brothers and sisters, they sometimes condemned me as unfaithful or not devout.

Those are the conditions in the environment of my cultural home that have made it all the more imperative for me to do something to help others_-as well as myself_-gain a better understanding about how to live a life of fidelity to Islam and genuine respect for religious "others" in a pluralistic society. I see myself, therefore, as one scholar called to develop, along with others, a Muslim theology of other religions and religious experience that at once will both strengthen the faith commitment of my fellow Muslims, as well as deepen their respect for the religious other and reinforce the tolerant ethos of Pancasila in my home country of Indonesia.

As a Muslim, I struggle every day with these important issues of inter-religious understanding and the absolute need to learn about the religious tradition and experience of the other by patiently listening to and observing what it is they say and do. Indeed, this is why I am pursuing both an ecumenical Doctor of Ministry and Ph.D. degrees sponsored by three Christian graduate schools of theology: Catholic Theological Union, the Lutheran School of Theology in Chicago, and McCormick Presbyterian Seminary. It is precisely my identity as an Indonesian Muslim, deeply concerned with the integrity of interreligious understanding and relations that I am studying for this degree. I am a Muslim who stands together with other Muslims who work to respond to the cry of those brands of contemporary Muslim 
renewal and reform that urge the Muslim community constantly to return to the revelation of the Qur'an and constantly ask how the revelation applies to the changing circumstances of our lives: "Back to the Qur'an and forward with Ijtihad." This means acting on these words of the famous poet, philosopher, and political theorist, Muhammad Iqbal: "The teaching of the Qur'an that life is a process of progressive creation necessitates that each generation, guided but unhampered by the work of its predecessors, should be permitted to solve its own problems" (Iqbal 1962, 168). These are useful guidelines today for liberation of all Muslims from traditional authoritarianism.

\section{Deeply Religious and Profoundly Ignorant of Religions}

As mentioned above, for decades, diversity in Indonesia was seen as a model of harmonious relations, where people of different religious backgrounds could live and cooperate peacefully. Indonesian Muslims were among the most peaceful and tolerant of the Islamic world. In the last decade or so, however, international media and academics have warned of rising intolerance in Indonesia. Especially since the downfall of Soeharto in 1998, radical Islam has been perhaps the most vivid and enduring image generated by Indonesia. Recently we also witnessed even more violent acts of intolerance directed to minorities in the country. Here religion has become lethal.

There are many reasons of conflicts (economic, social, and politics), but one of the causes I believe is religious illiteracy. Here I do not mean only those who are illiterate about their own traditions; instead, I am wondering if Indonesians are both deeply religious and profoundly ignorant of religions.

It is common in many religious traditions that exclusivist tendencies are likely to be uninformed from within as well as from without (Almirzanah 2011, 231). Uninformed from within means they are usually deaf to alternative interpretative possibilities from inside their own tradition. Uninformed from without, means they are usually articulated with little to no experience of genuine encounters with the other, or if there is experience of the other, it is short-lived and highly negative.

${ }^{1}$ In general usage, the Arabic word ijtihad denotes the utmost effort, physical or mental, expended in a particular activity. In its technical legal connotation, it denotes the thorough exertion of the jurist's mental faculty in finding a solution for a case of law. See Wael B. Hallaq, "Ijtihad," in The Oxford encyclopedia of the modern Islamic world, Vol. 2, ed. John L. Esposito, 178. New York: Oxford University Press, 1995. 
The impact of this religious ignorance is actually deeper. That great pioneer of the modern discipline of the history of religions, Friedrich Max Muller, once famously wrote, "He who knows one religion knows none" (Muller 1873, 16), perhaps largely referring in his own scholarly context to those who aspired to become experts in the study of a particular religious tradition. Yet today, this dictum seems to have significance well beyond the membership of the American Academy of Religion and similar scholarly societies. In today's increasingly religiously plural social contexts, these words suggest that a failure to engage pluralism is an act of self-marginalization within our own social contexts. Furthermore, without some understanding of the faith of our neighbor, the religious person (or community) living in a religiously plural society cannot even understand oneself (or itself).

Whether one is religious or not, understanding religion is a key to understanding other cultures. In addition, racial and religious prejudices are major issues in the contemporary world, including Indonesia. One major motive in the understanding of religions is to encourage knowledge and understanding between religions and cultures, based on the assumption that prejudice will be overcome if each knows more about the other. It is hoped that knowledge of others will result in understanding and better relations between peoples. Above all, the understanding of other religions (including diversity within religious traditions) is to enable us to "see through the spectacles" of other cultures. If someone can develop an empathetic understanding of another culture, the result will be that they are more ready to empathize with other cultures as well.

\section{Intuitive versus Concretist}

In my book entitled Ketika Makkah Menjadi Seperti Las Vegas: Agama, Politik, dan Ideologi (When Mecca Becomes Las Vegas; 2014), I am dealing with the tendencies toward a literal and formalist understanding of religion in Indonesia in relation to the rise of intolerance among some religious people. Psychologically speaking human beings tend to organize their environment in a very simple cognitive structure. According to Olufemi A. Lawal in an article entitled, "How a Terrorist May Develop in Individual," it seems that human beings need a "cognitive closure"- an exact answer to certain problems and "opposed to confusion and ambiguity." These tendencies, which is the characteristic of much of the fundamentalist, Lawal insists, can be encountered not only in non-Western society; 
they are also in developing societies, which are "the few societies that can be described as the capital of terrorism" (Lawal 2002, 4, 12, 29).

Thus, according to Jungian personality theory, there are two basic types of human being, abstract/intuitive (intuitive) and concrete/ objective (concretist/certainty-seeking). The intuitive person-usually people with social sciences and art background - tends to be more creative in solving problems, explores feelings and instinct, and has new ideas that are more imaginative, problem-oriented and subjective. On the other hand, the concretist "prefer a concrete way of perceiving the world,... perhaps simple and possibly simplistic, and strongly 'solution-oriented."' It means, if intuitives look at "what could be, concretists look at "what is"' (Johnson 2004, 200-202). ${ }^{2}$ Consequently, many people find it difficult to face change in their lives. They are relatively less equipped to solve what Jessica Stern called "a surfeit of choice." Furthermore, according to Stern in Terror in the Name of God: Why Religious Militants Kill, for concretists, too many choices "can be overwhelming and even frightening" (Stern 2003, 69). ${ }^{3}$ It is for this reason that religious fundamentalism, for example, is very attractive for the concretists (see Emerson 2002, 172). ${ }^{4}$ Thus, they are engaged in what Malise Ruthven called "monodimensional or literalist readings of scripture," which contrast to those in the intuitive group, "who have been trained to approach the text in multidimensional approaches" (Ruthven 2002, 103). In A Fury for God, Ruthven indeed argues that Islamist leaders are characteristically those who revive childhood mythology with a monodimensional rationalism (see Ruthven 2002).

In this case Abdurrahman Wahid, Indonesian former president, has said some who have a concretist orientation, even if educated in technology, have a formalistic faith expression, or sometimes use the text in a reductionistic fashion with no capacity to appreciate its inherent meaning (Wahid 2002). ${ }^{6}$ In a similar manner Khalid Duran, an

${ }^{2}$ Quoted by Ramakrishna, The making of Jemaah Islamiyah Terrorist, in James J. F. Forest, Teaching Terror: Strategic and Tactical Learning in the Terrorist World. Lanham, MD: Rowan and Littlefield Publisher, 2006, p. 242.

${ }^{3}$ Quoted by Ramakrishna, Ibid.

${ }^{4}$ Ramakrishna quoted this also from R. Johnson, "Psychological Roots of Violence: The Search for the Concrete in a World of Abstracts," in Ellens, Ed., Destructive Power of Religion, Vol.4, Contemporary Views on Spirituality and Violence, 200-202.

${ }^{5}$ Quoted by E. B. Desker and A. Acharya, 2006, "Countering the Global Islamist Terrorist Threat," The Korean Journal of Defense Analysis.

${ }^{6}$ Quoted in K. Ramakrishna, 2009, Radical Pathways: Understanding Muslim Radicalization in Indonesia. Westport, CT: Greenwood Publishing. 
Arabic scholar, who with his broad knowledge becomes an ambassador of moderate Islam and Emerson's translator, believes that "having an education in literature or politics or sociology seems to inoculate you against the appeals of fundamentalism" (Emerson 2002, 173). ${ }^{7}$

The relationship between "formalistic understanding of Islamic law" and "violent radicalism," is an important problem about which we should concerned. Moojan Momen in "Fundamentalism and Liberalism: Toward an Understanding of the Dichotomy," argues that for fundamentalists, uncertainty is very unsatisfying. Fundamentalists (in this sense also concretists) tend to seek an ideological or religious system that satisfies-with "no ambiguities, no equivocations, no reservations, and no criticism" (Momen 1992, 17). It is because of their overwhelming desire for certainty. Everything considered to be in opposition to a concrete belief can provoke aggression (Olweean 2002, 116). In the same manner, Stuart Sim maintains that unlike postmoderm thought, that does not believe in certainty, individuals with fundamentalist mentality will have a "desire for certainty" and, at the same time, will actively look for "the power to enforce that certainty over others" (Sim 2004, 29). This describes clearly of what is happening in Indonesia.

In this condition reform is desperately needed. The tasks of religious leaders are expanded beyond combating terrorism, which is being accomplished internationally and nationally, but they also must collaborate on reforming the curriculum in madrasah (Islamic school), seminary, school, university.

If we recount to the Qur'an or/and the Bible, plurality can be learned from the story in both scriptures about Moses. In both scriptures, it is said that "Moses as a baby was made by God to refuse the milk of all but his own mother; by this means she was eventually reunited with her son." Al-Sheikh al-Akbar, an Andalusian Sufi, Ibn Arabi, in his book Fusus al-Hikam (The Bezels of Wisdom 1980), tells the story and then adds the verse "For each of you We appointed "Shir'ah" dan "Minhaj" ("a revealed law and a way") (5: 48). Sheikh continues by saying that "the milk signifies that 'way' which provides the sustenance for the laws prescribed to all the people, just like the branches of the trees can only feed from their roots" (Kazemi 2006,

${ }^{7}$ On 2001, when Duran published a book entitled Children of Abraham: An Introduction to Islam for Jews, he was condemned by CAIR as not "real Muslim" even considered to be an apostate in Ash-Shahid, a Jordanian newspaper. See Khalid Duran, 2002, How CAIR Put My Life in Peril, Middle East Quarterly, Winter, pp. 37-43. http:/www.meforum.org/108/how-cair-put-my-life-in-peril. 
122). "The fact that it was only his mother's milk that could nourish Moses did not signify that the milk of other mothers was not nutritious; so, the fact that one's own 'way' satisfies one's own religious needs does not signify that other 'ways' are intrinsically incapable of providing for religious needs of their own respective communities" (122).

Thus the problem of religious knowledge is an individual need of every religious community; no one has the right to force another; neither does the state. ${ }^{8}$ Moreover, Indonesia is not a theocratic fundamentalist state that supports a radical interpretation of Islam. "Religiosity is people's understanding of religion just as science is their understanding of nature" (Soroush 2009, 15). Ibn al-Arabi said that "the word of the Qur'an-not to mention the verse and chapter-has an infinite meaning, all of which are intended by God" (Ibn al-Arabi, 1972, 367.3). ${ }^{9}$ Normativity has to be differentiated with historicity (see Abdullah 1996). It is a manifestation of the supernatural into the natural (see Soroush 1998). The Qur'an was revealed into the earth of interpretation via the angel of reason, after it was revealed to the Prophet. In other words, we see the revelation from the interpretation, exactly like a faithful scientist looks at the universe as the artifact of the Creator. Muhammad Shahrur in his book entitled al Kitab walQur'an, Qiraah mu'asiroh (the Book and the Qur'an: A contemporary reading), asks the readers to understand the Qur'an "as if the Prophet has just died and informed us this book" (ka'anna al-nabi tuwuffiya hadithan wa-ballaghana hadha l-kitab) (Shahrur 2003).

\section{POST SCRIPT}

Religious pluralism is not simple recognition of the fact that there are different religions and faiths in a society or a country, but an appreciation that the fact of the religious plurality has a positive value. To be a pluralist is not merely to be tolerant. Religious pluralism calls for active engagement with the religious other not merely to tolerate, but to understand. It is in this context that religious pluralism should be

${ }^{8}$ The case for Shi'a community forced by the state authority to follow its interpretation on certain religious edict was an example of how the authority imposes its religious understanding/knowledge to the people with different religious orientation.

${ }^{9}$ Quoted in Almirzanah, Syafaatun, When Mystic Masters Meet: Toward a New Matrix for Christian-Muslim Dialogue. Clifton, NJ: Blue Dome Publication, 2011, 167. 
grounded in the theological acceptance of the others as God's design for humanity. Theologically speaking, religious pluralism is divinely ordained system.

In this situation it is important to reconstruct "diversity." Rabbi Jonathan Sacks asserts that part of the creative genius of Rabbinic Judaism is that it pioneered not one, but two, ideals of peace. The first is the ultimate "messianic" peace in which all divisions among humankind will be dissolved and all tensions resolved. Perhaps the most well-known biblical text expressing this messianic ideal is Isaiah 11:6-9, beginning with the famous words, "The wolf shall live with the lamb, the leopard shall lie down with the kid, the calf and the lion and the fatling together, and a little child shall lead them."

For Sacks, the genius of Jewish teachings regarding peace is that it complements the messianic ideal with a practical ideal of a "hereand-now peace which depends on different groups with incompatible ideals living graciously or at least civilly together without attempting to impose its beliefs on others" (Sacks 2002, 10).

In fact, this is what we should pursue in today's multi-religious world. Religious plurality is the very embodiment of what it means to be the One. When viewed from "outside," the pluralism of religions appears to be problematic, disjunctive, and competing; but seen from "within" pluralism becomes an expression of the inclusiveness of the One, the Ultimate, which is multidimensional.

Education is the main factor to face the problem described above. Especially in this case, how education is enriched by methodology that encourages the students to have critical thinking. Beit-Hallahmi and Michael Argylle $(1997,115)$ opine that "natural sciences apply critical thinking to nature, the human sciences ask critical questions about culture, tradition and beliefs." Duran opines that an engineer is not trained to "exercise their fantasy and imagination. Everything is precise and mathematical.. .. They don't study what we call 'the humanities'. Consequently when it comes to issues that involve religion and personal emotion, they tend to see things in very stark terms" (Emerson 2002, 173). ${ }^{10}$ A systematic and comprehensive education that trains "critical analysis" and "thinking skills" needs to be reached. Exact science and technical education is important, but it needs to

${ }^{10}$ Quoted by Ramakrishna, Madrassas, Pesantrens, and the Impact of Education on Support for Radicalism, in Joseph McMillan, 2006, "In the Same Light as Slavery": Building a Global Antiterrorist Consensus. Washington, DC: Institute for National Strategic Studies National Defense University Press. 
be balanced by disciplines, such art and humanities, with the stressing on social analysis of social life. Intuitive mentality needs to be increased, as Kimball says, only when people learn how to question the dogma in all social life, including religion, the worse influence concretist/fundamentalist mindset, could be avoided.

Syafaatun Almirzanah, Ph.D., D. Min. teaches at the State Islamic University Sunan Kalijaga Jalan Marsda Adisucipto in Yogyakarta, Indonesia. E-mail: shafaelmirzana@gmail.com

\section{REFERENCES}

Abdullah, S., 1996. Studi Agama Normativitas atau Historisitas [Religious studies, Normativity and Historicity]. Yogyakarta: Pustaka Pelajar, 1996.

al-Arabi, I., and M. al-Din. 1980. The bezels of wisdom, translation and introd. by R.W.J. Austin; pref. by Titus Burckhardt. New York: Paulist Press.

al-Arabi, I., and al-Futuhat al-Makkiya (eds.). 1972. 'Uthman Yahya. Cairo: al-Hay'at al-Misriyat al-'Amma li al-Kitab.

Almirzanah, S. 2011. When mystic masters meet: Toward a new matrix for Christian-Muslim dialogue. Clifton, NJ: Blue Dome Publication.

Emerson, S. 2002. American Jihad: The terrorists living among us. New York: The Free Press.

Hallaq, W. B. 1995. "Ijtihad," in The Oxford encyclopedia of the modern Islamic world, Vol. 2, ed. J. L. Esposito, 178. New York: Oxford University Press.

Iqbal, M. 1962. The reconstruction of religious thought in Islam. Lahore: Shaikh Muhammad Ashraf.

Johnson, R. 2004. Psychoreligious roots of violence: The search for the concrete in a world of abstractions. In The destructive power of religion, vol. 4: Contemporary views on spirituality and violence, ed. J. H. Ellens, 200-202. Westport, CT: Praeger Publishers.

Kazemi, R. S. 2006. Paths to transcendence according to Shankara, Ibn Arabi, and Meister Eckhart. Bloomington, IN: World Wisdom.

Lawal, O. A., 2002. How a terrorist may develop in individual. In The psychology of terrorism, Program and practice in response and prevention, Vol. 4, ed. C. Stout, 23-32. Westport, CT: Praeger Publishers.

Momen, M. 1992. Fundamentalism and liberalism: Towards an understanding of the dichotomy. Reason and Revelation, Studies in the Babi and Baha'i Religion, Vol. 13. Los Angeles, CA: Kalimat Press. Originally published in 1992, Baha'i Studies Review, Volume 2:1.

Muller, F. M. 1873. Introduction to the Science of Religion. London: Longman Green.

Olweean, S. 2002. Psychological concepts of the "Other": Embracing the compass of the self. In Psychology of terrorism: Vol. 1, ed. C. Stout, 113-128. Westport, CT: Praeger Publishers.

Pope John Paul II. 1986. Address of John Paul to Representatives of the Christian Churches and Ecclessial Communities Gathered in Assisi for the World Day Prayers, Basilica of St. Mary of the Angel, 27 October, 1986. http://www.vatican.va/holy_father/john_paul_ii/speeches/ 1986/october/documents/hf_jp-ii_spe_19861027_prayer-peace-assisi-final_en.html

Ramakrishna. 2006. Madrassas, Pesantrens, and the Impact of Education on Support for Radicalism. In "In the Same Light as Slavery": Building a Global Antiterrorist Consensus, ed. J. McMillan, 2006. Washington, DC: Institute for National Strategic Studies National Defense University Press.

Ramakrishna. 2009. Radical Pathways: Understanding Muslim Radicalization in Indonesia. Westport, CT: Greenwood Publishing.

Ruthven, M. 2002. A Fury for God: The Islamic Attack on America. New York: Granta. 
Sacks, J. 2002. A clash of civilization? Judaic sources on co-existence in a world of difference. http://ocrweb.trci.com

Shahrur, M. 2003. al-Kitab wa'l-quran: qiraa muasira, 1992, dikutip oleh Andreas Christmann dalam "The Form Is Permanent, but the Content Moves": The Qur'anic Text and Its Interpretation(S)in Mohamad Shahrour's 'Al-Kitāb wa 'l Qur'ān', Die Welt des Islams. New Series 43 (2): 143-144.

Sim, S. 2004. Fundamentalist world: The new dark age of dogma. Cambridge: Icon Books.

Soroush. 1998. Text in context. In Liberal Islam: A sourcebook, ed. C. Kurzman, 244-251. Oxford: Oxford University Press.

. 2009. Reason, freedom, and democracy in Islam: Essential writings of Abdoul Karim Soroush, trans. Mahmoud Sadri and Ahmad Sadri. Oxford: Oxford University Press.

Stern, J. 2003. Terror in the name of God: Why religious militants kill. New York: Harper-Collins. Wahid, A. 2002. Best way to fight Islamic extremism. The Sunday Times (Singapore), April 14. 